\title{
D oes hypocrisy matter? The case of US foreign policy
}

\author{
DARYL GLASER
}

\begin{abstract}
A bstract. US foreign policy is hypocritical in various ways, as this article demonstrates in the course of an extensive empirical review. The question is whether such hypocrisy provides grounds for opposing U S interventions abroad, in particular those which might yield locally desirable outcomes at an acceptable human cost. This article examines the question from the standpoint of a non-pacifist liberal universalism and concludes (on consequentialist grounds) that the hypocritical character of U S foreign policy cannot constitute sufficient grounds for rejecting all U S interventions. N evertheless, the hypocrisy of the U S remains noteworthy and deserving of criticism even in such cases because of the wider damage hypocritical behaviour can do. Moreover, US foreign policy hypocrisy sometimes sets in motion reactions that confound the benign purposes of particular interventions and so undermine the case for them. Such an effect is at work in the case of recent U S intervention in the M iddle East.
\end{abstract}

\section{Introduction}

In its 'war on terrorism' since September 11th, 2001 the U nited States has portrayed itself as the vanguard of freedom-loving civilisation locked in combat with 'evildoers'. M any people with diverse views about A merica's recent international conduct find this portrayal hypocritical. But if it is, does such hypocrisy matter? Should it be a consideration in judging whether the US ought to intervene militarily against bad governments or movements? If particular U S interventions seem likely to produce 'locally' desirable outcomes, should it be concerning that US governments have behaved inconsistently and dishonestly over the years, and have often been pretty bad themselves?

Terms like 'bad' (and conversely 'good') are measures internal to moral and philosophical systems. The system informing their use here is liberal and universalist. It is liberal in that it is premised on the equal right of individuals to liberty and autonomy; and universalist in seeking application to individuals in all countries, irrespective of their legal systems, concepts of right and local loyalties. The moral-philosophical system behind these reflections is also non-pacifist, since it sanctions the use of certain types of force under certain circumstances to secure just ends. Stated at this general level, liberalism encompasses left-wing and right-wing variants, which it is not necessary to distinguish for present purposes. Liberalism thus loosely defined is subscribed to by much of A merica's political elite, as well as by many critics of US power. F or this reason, it provides both widely shared normative terms of reference for a discussion of U S foreign policy and a yardstick by which can 
be measured A merica's faithfulness to its own professed beliefs. The absence of such fealty constitutes the essence of US hypocrisy.

$\mathrm{H}$ ypocrisy is here treated as a label for action that fails to live up to proclaimed principles or adheres to them selectively. U nlike the morally weak, hypocrites pretend that they are virtuous in ways that their actions contradict. ${ }^{1} \mathrm{H}$ ypocritical behaviour can be cynically aimed at deceiving others about the hypocrite's moral character or can arise from one or another form of self-deception. ${ }^{2}$ C risp and Cowton identify four types of hypocrisy: pretence of moral goodness, moral criticism of others by those possessing faults of their own, failure to satisfy self-acknowledged moral requirements and a complacent, unreflective commitment to virtues feigned or preached. ${ }^{3}$ While the hypocrisy discussed here likely involves elements of all four types, this article is not mainly concerned with whether the US foreign policy establishment is cynical, self-deceived or morally unreflective. Rather than inquire into the inner mental state of the A merican political elite, its focus is on proclaimed principles, observable deeds and real-world consequences. While hypocrisy elicits reasonable doubts about the hypocrite's motivations and future intentions, demonstrating hypocrisy does not require insight into the thought processes of those suspected of it. To establish the premise of this article - that the US is hypocritical in important ways - it is necessary and sufficient to demonstrate two things. O ne is that the U S does not practice what it preaches. The other is that a state is the sort of moral actor against which the charge of hypocrisy can properly be levelled.

\section{The state as moral actor}

If currency in ordinary language is the measure, there is no difficulty in attributing moral agency to a state. The A merican state, for one, has been accused of hypocrisy by countless critics. Equally the laws of many countries attribute moral personality to organisations. They do so properly, since organisations carry out actions that have consequences for people. These actions are often the product of organisational processes - rules, rituals, cultures, collective action effects - rather than of single or particular individuals. Where an actor needs to be held accountable for them, it may thus be an organisation, not persons. This stricture holds true for the U S.

Even so, vesting moral agency in an organisation is not unproblematic. An organisational vice may be an outcome of disparate inputs, some perhaps virtuous, others not. The state's internal diversity blurs its moral identity in ways especially problematic for the charge of hypocrisy. D uring a given administration the president, advisers or indeed departments might be morally consistent in themselves, yet in combination may seem hypocritical. Equally, administrations might be consistent in themselves, yet inconsistent with previous administrations. There is plentiful

1 Béla Szabados, 'H ypocrisy', Canadian Journal of Philosophy, 9:2 (1979), pp. 195-210, at 198-200; Béla Szabados and Eldon Soifer, 'H ypocrisy, Change of $M$ ind, and Weakness of Will: How To Do M oral Philosophy with Examples', Metaphilosophy, 30:1/2 (1999), pp. 60-78, at 66-71; James Spiegel, Hypocrisy: Moral Fraud and other Vices (Grand Rapids, M I: Baker Books, 1999), pp. 37-40.

2 Szabados, 'H ypocrisy', pp. 206-10; Spiegel, Hypocrisy, pp. 44-67.

3 R oger Crisp and Christopher Cowton, 'H ypocrisy and M oral Seriousness', American Philosophical Quarterly, 31:4 (1994), pp. 343-9, at 343-5. 
evidence of intra-bureaucratic, partisan and personality factionalism, as well as of executive-Congress tension, in the making of A merican foreign policy. ${ }^{4}$ There have unsurprisingly also been significant foreign policy shifts across time. ${ }^{5}$

$\mathrm{N}$ one of this matters if we take to its logical conclusion the view that the state is nevertheless the resultant of these disparate elements. The problem with going all that way is that it leaves unclear how current state personnel are meant to act in light of the hypocrisy charge. Must one official refrain from publicly advocating global democracy because other officials support authoritarian overseas allies? If an incumbent administration acts idealistically, is it morally improving the state or rendering it still more historically inconsistent? While the state is in some ways unitary and collective, in others it is multiple and individuated. F or a charge against an organisation to carry morally constructive force, it must have identifiable implications for individual as well as organisational behaviour.

We can rescue the state's moral agency provided that we specify (1) what individuals can do to escape or act on a corporate accusation and (2) what can by done (by individuals or systemically) to enable the organisation as a whole to escape or act on an accusation. In the case of state hypocrisy, requirement (1) can be met by affirming that individuals or organs within a hypocritical state are not necessarily hypocritical themselves. Individual politicians and bureaucrats can avoid the charge provided they act non-hypocritically during their own tenure and across the whole of their jurisdiction. They are moreover not disqualified from doing good, or personally opened to the charge of hypocrisy, by the inconsistency of their praiseworthy action with the words and actions of predecessors or personnel outside their control. Those levelling the hypocrisy charge ought, on their side, to specify the accused more clearly, even if victims of injustice are excused the obligation to draw finer distinctions. I am directing my own charge of hypocrisy against the US as an organisation, though it seems applicable to all recent U S administrations separately.

How, to satisfy (2), can a state cease to be hypocritical? For one, it must act morally consistently at a given time, where that time coincides with the present and encompasses at least, say, a single presidential administration in the US (or as much of it as has played out). In addition, the current government must renounce the contradicting actions of predecessors and officials and, indeed, to do so in some sense on behalf of the state. $R$ enunciation by the state of bad actions requires that it issue official apologies, redress injustices, provide compensation, undertake institutional reforms to guard against repeat offending, change the way issues are taught in public schools, initiate a process of glasnost including the declassification of information, and acknowledge past errors in everyday public rhetoric. When in 1999 President

4 J ohn D umbrell, The Making of US Foreign Policy (M anchester: M anchester U niversity Press, 1990); A dam Garfinkle, 'F riendly Tyrants: H istorical R eckoning', in D aniel Pipes and A dam G arfinkle (eds.), Friendly Tyrants: An American Dilemma (Basingstoke, U K : M acmillan Press, 1991),

pp. 221-51, at 242-6; M ichael J. Hogan, 'Partisan Politics and F oreign Policy in the A merican

Century', in M ichael J. Hogan (ed.), The Ambiguous Legacy: US Foreign Relations in the 'American Century' (Cambridge, U K : Cambridge U niversity Press, 1999), pp. 356-77; M ichael M astanduno,

'The U nited States Political System and International L eadership: A "D ecidedly Inferior" F orm of Government?', in G. John I kenberry (ed.), American Foreign Policy: Theoretical Essays (N ew Y ork: Longman, 1999), pp. 279-99; Clyde Prestowitz, Rogue Nation: American Unilateralism and the Failure of Good Intentions (N ew Y ork: Basic Books, 2003), pp. 225-6.

5 J ames E. Dougherty and R obert L. Pfaltzgraff, American Foreign Policy: FDR to Reagan (Cambridge, M A : H arper \& R ow, 1986); H. W. Brands, 'The I dea of the N ational Interest', in Hogan (ed.), The Ambiguous Legacy, pp. 120-51. 
Clinton issued an apology for past A merican dealings in Central A merica, urging that the U S not repeat its mistakes in the region, ${ }^{6}$ he fulfilled just one requirement of (2).

In addition to showing that states can be moral actors it is also necessary, I indicated earlier, to demonstrate that A merican actions are inconsistent with US public value commitments. The task of illustrating a disparity between the two falls to the next two sections. The more intriguing and central question of whether hypocrisy is bad enough to disqualify a military intervention, and if so why and when, will be addressed after that.

\section{W hat A merica preaches}

Since at least 1917, when President Wilson enunciated his F ourteen Points, the U S has publicly committed itself to supporting democratic self-government and human rights both at home and abroad. The US has frequently chided others for violating one or both; and considers itself a beacon for these principles in the world, advancing their cause everywhere against various kinds of opposition, including Communist, authoritarian-nationalist, $\mathrm{N}$ azi and Islamic fundamentalist. Thus Wilson, facing German militarism, promised to 'make the world safe for democracy', President Truman 'to support free peoples' against Communism and the U nited States $\mathrm{N}$ ational Security Strategy of 2002 to 'extend the benefits of freedom across the globe' in the wake of the al Q aeda attacks of September 11th 2001. A number of writers have emphasised the centrality of moral ideals to A merica's sense of self, suggesting that it has given a peculiar slant to A merica's projection of itself abroad. ${ }^{7}$

The content of A merica's creed of freedom has shifted in certain ways. It was initially more liberal than democratic, for example. I will take as my own yardstick the U S's later-developing commitment to both liberalism and democracy in the shape of liberal democracy, though the democracy and rights elements will be addressed separately in my demonstration of US theory-practice discrepancy.

Some of what the A merican creed has come to include will not be drawn into my demonstration, above all the belief in the intimate connection between democracy and markets. ${ }^{8}$ W hile A merica's positive moral evaluation of capitalism may help explain its Cold War prioritisation of anti-leftism over democracy (I return to this later), I will not document inconsistencies in US practice with respect to marketadvocacy (such as President Bush's recent steel tariffs, now rescinded, and his farm

${ }^{6}$ Barry K. Gills, 'A merican Power, N eo-L iberal Economic G lobalization, and L ow-Intensity Democracy: An Unstable Trinity', in M ichael Cox, G. J ohn I kenberry and Takashi Inoguchi (eds.), American Democracy Promotion: Impulses, Strategies, and Impacts (Oxford: Oxford U niversity Press, 2000), pp. 326-44, at 327.

7 See, for example, D ougherty and Pfaltzgraff, American Foreign Policy, p. 3; D umbrell, The Making of US Foreign Policy, pp. 21-2; A dam Garfinkle, 'F riendly Tyrants', pp. 221-32, 238-40; H enry R. Luce, 'The A merican Century', in Hogan (ed.), The Ambiguous Legacy, pp. 11-29.

8 Brands, 'The Idea'; J oan H off, 'The A merican Century: From Sarajevo to Sarajevo', in Hogan (ed.), The Ambiguous Legacy, pp. 183-231; Walter LaF eber, 'The Tension Between D emocracy and Capitalism during the A merican Century', in Hogan (ed.), The Ambiguous Legacy, pp. 152-82; Tony Smith, 'M aking the World Safe for D emocracy in the A merican Century', in Hogan (ed.), The Ambiguous Legacy, pp. 30-51; M ichael Cox, 'W ilsonianism R esurgent: The Clinton A dministration and the Promotion of Democracy', in Cox, Ikenberry and Inoguchi (eds.), American Democracy 
subsidies). M y concern here is with A merica's (in)consistency as a promoter of liberal and democratic principles outside the realm of economic exchange.

$R$ adical democrats have long criticised as thinly formalistic the model of democracy operative in the US and elsewhere in the W est. R ecently they have taken the US to task for promoting a similarly 'low-intensity' or 'polyarchic' model of democracy abroad. This model, these radicals argue, privileges free elections over social equality, economic democracy and popular participation. ${ }^{9}$ I will make some critical remarks of my own about the quality of domestic A merican democracy. M y focus in respect of US foreign policy, however, will be on flagrant breaches of democratic and human rights values. While the practice of elitist democracy is arguably hypocritical for a country that trumpets its democratic superiority, it is not obvious that in operating or exporting polyarchy the US is breaching publicly affirmed values. It is against US support for authoritarian and crudely oppressive forces that the charge of hypocrisy is most readily laid. Instances of the latter predominate in the charge sheet that follows.

It should be acknowledged that if the US does not always promote liberty and democracy, nor does it always preach them. Influential A merican 'realists' have insisted that global relationships are necessarily governed by the interplay of selfinterested states. While differing in their prescriptions for the US - for example, on whether it should be cautious or aggressive abroad - they have shared a scepticism about universalistic schemes for promoting democracy and rights. ${ }^{10}$ To the extent that realism has prevailed in A merican foreign policy counsel, some might argue, the charge of hypocrisy is irrelevant, since realists do not pretend to virtue in the first place.

I concede something to this point: the hypocrisy charge sticks better to the more preachy American politicians. Still, a manipulative realist might feign belief in liberal-democratic values the better to advance American interests, and that would count as hypocrisy. ${ }^{11} \mathrm{M}$ ore importantly, the realist strand in US foreign

Promotion, pp. 218-39; G. J ohn Ikenberry, 'A merica's L iberal G rand Strategy: Democracy and $\mathrm{N}$ ational Security in the Post-war Era', in Cox, Ikenberry and Inoguchi (eds.), American Democracy Promotion, pp. 103-26, at 113-20; Chalmers Johnson, Blowback: The Costs and Consequences of American Empire ( $\mathrm{N}$ ew Y ork: M etropolitan Books/H enry $\mathrm{H}$ olt and Co., 2000); A ndrew J. Bacevich, American Empire: The Realities and Consequences of US Diplomacy (Cambridge, M A : Harvard U niversity Press, 2002).

9 Barry Gills and J oel R ocamora (1992), 'Low Intensity Democracy', Third World Quarterly, 13:3 (1992), pp. 501-23; Barry Gills, J oel Rocamora and R ichard Wilson (eds.), Low Intensity Democracy: Political Power in the New World Order (L ondon: Pluto, 1993); W illiam I. R obinson, Promoting Polyarchy: Globalization, US Intervention, and Hegemony (Cambridge: Cambridge U niversity Press, 1996); W illiam I. R obinson, 'Promoting Capitalist Polyarchy: The Case of L atin A merica', in Cox, Ikenberry and Inoguchi (eds.), American Democracy Promotion, pp. 308-25; Gills, 'A merican Power'; Steve Smith, 'U S D emocracy Promotion: Critical Questions', in Cox, I kenberry and Inoguchi (eds.), American Democracy Promotion, pp. 63-82.

$10 \mathrm{~F}$ or recent discussions on or by the A merican realists, see D umbrell, The Making, pp. 7-24; G arfinkle, 'F riendly Tyrants'; Brands, 'The I dea', pp. 120-30; Samuel P. H untington, 'A merican I deals versus A merican Institutions', in Ikenberry (ed.), American Foreign Policy, pp. 221-54; L aF eber, 'The Tension', pp. 159-60, 177-8; Smith, 'M aking the World Safe', pp. 33-4; M ichael D oyle, 'Peace, Liberty, and D emocracy: R ealists and L iberals Contest a L egacy', in Cox, Ikenberry and Inoguchi (eds.), American Democracy Promotion, pp. 21-40.

11 Some writers argue that democracy promotion was itself an A merican realist strategy, since democracies abroad enable A merica to live in a peaceful, trade-friendly environment. See Cox, 'W ilsonianism resurgent'; I kenberry, 'A merica's L iberal G rand Strategy'; T ony Smith, 'N ational Security Liberalism and A merican Foreign Policy', in Cox, Ikenberry and Inoguchi (eds.), American Democracy Promotion, pp. 85-102. But even if US strategists thought that some of the time, they must at least often have concluded that realist considerations militated against promoting democracy abroad. 
policymaking has not prevented a considerable continuity in U S public advocacy of freedom and democracy, whether sincerely meant or not. That fact is sufficient to establish one of the coordinates of the hypocrisy charge: that A merica preaches certain principles at home and abroad.

The realist strand in A merican foreign policy is usefully juxtaposed to another that sets up the U S rather well for moral consideration: the religious. Powerful biblicalreligious impulses run through A merican public culture. These lend a $M$ anichaean cast to many U S foreign policy pronouncements. ${ }^{12}$ Presidents like W ilson and $\mathrm{G}$. W . Bush have appeared to view the US as divinely chosen to battle global evil. In its advocacy of freedom and democracy the $U S$ thus sometimes literally seems to preach.

\section{A merican practice}

A s will later be more fully acknowledged, the U $S$ has, in certain times and places, lived up to its democracy- and rights-promoting creed. But it has very often not. That this is so can be easily shown. The demonstration is nevertheless worth undertaking, because it points to truths that the A merican political class (and public) rarely acknowledge.

The US has failed in various ways to advance the cause of liberal democracy internationally. ${ }^{13}$ The least flagrant instances are where it chooses to coexist with an undemocratic power on prudential grounds. Taking on that power (say, if it is nuclear-armed) may be too dangerous for itself and the world. Sometimes such considerations become mixed with more self-interested ones to do with, say, trade; but even then we cannot talk of the U S actively propping up such regimes, and its cooperation with them is tempered by various degrees of criticism of their record. Periods of U S détente with the Soviet U nion and current pragmatic relations with the People's R epublic of China are instances of such 'realism'.

$M$ ore interesting are those occasions when the $U \mathrm{~S}$ has been an active opponent of democracy. A merican governments directly aided the armed overthrow of elected leaders in the following instances: I ran 1953, together with B ritain; G uatemala 1954; D ominican R epublic 1965; Chile 1973; and N icaragua (1980s). On other occasions, such as Congo 1961, Brazil 1964 and Cyprus 1974, the US tacitly backed the overthrow of elected or democratically legitimate leaders. In some of these cases the US proceeded to re-establish electoral democracy on its own terms (Dominican $\mathrm{R}$ epublic, $\mathrm{N}$ icaragua); in other cases its intervention led to long periods of repressive U S-backed dictatorship (Iran, Guatemala, Chile). ${ }^{14}$

12 G arfinkle, 'F riendly Tyrants', pp. 221-2; Brands, 'The Idea', pp. 132-4; Prestowitz, Rogue Nation, p. 41.

${ }^{13}$ U S support for anti-democratic forces is documented in numerous places. U seful general sources include N oam Chomsky, Deterring Democracy (L ondon: Verso, 1991); Pipes and G arfinkle (eds.), Friendly Tyrants; L aF eber, 'The Tension'; Christopher $\mathrm{H}$ itchens, 'The Case against $\mathrm{H}$ enry $\mathrm{K}$ issinger, F ormer Secretary of State, U nited States', Harper's Magazine, F ebruary 2001; M ax Boot, The Savage Wars of Peace: Small Wars and the Rise of American Power (N ew Y ork: Basic Books, 2002); and William Blum, Rogue State: A Guide to the World's Only Superpower (L ondon: Zed Books, 2002).

${ }^{14}$ Sources for this paragraph include A dam G arfinkle and A lan L uxenberg, 'The First F riendly Tyrants', in Pipes and Garfinkle (eds.), Friendly Tyrants, pp. 23-40; Barry R ubin, 'Too Little, Too Late: A merican Policy and the Shah of I ran', in Pipes and G arfinkle (eds.), Friendly Tyrants, pp. 131-50; H itchens, 'The Case'; L aF eber, 'The Tension', pp. 170-2; Blum, Rogue State; D uncan Campbell, 'K issinger A pproved A rgentinian "Dirty War" ', The Guardian, 5 D ecember 2003; Stephen K inzer, 'I ran and G uatemala, 1953-4: R evisiting Cold War Coups and Finding Them Costly, NYTimes.com, 30 N ovember 2003; Stephen K inzer, All the Shah's Men: An American Coup and the Roots of Middle East Terror (N ew Y ork: J ohn Wiley, 2003); Prestowitz, Rogue Nation, pp. 184-6. 
The US has offered variable degrees of support to many authoritarian regimes, often against oppositions that included democratically promising elements. U nder this heading can be placed countries in Latin A merica (Stroessner's Paraguay, A rgentina's military dictatorship 1976-83, Nicaragua under the Somozas, $\mathrm{H}$ aiti under the D uvaliers), southern E urope (Salazar's Portugal, F ranco's Spain, G reece's 1967-74 dictatorship, dictatorial interludes in Turkey), eastern A sia (South Korea and Taiwan from the 1940s until the later 1980s, M arcos's Philippines) and Sub-Saharan A frica (M obutu's Congo/Zaire, Liberia).15

In another set of cases, the US has (to be sure) opposed undemocratic governments, but on behalf of other undemocratic governments. Thus the US backed authoritarian anti-communist regimes against $\mathrm{Communist}$ opponents (in the $\mathrm{K}$ orean and Indo-China wars); anti-M oscow Communists (China, Ceausescu's R umania, even the K hmer R ouge in post-1979 Cambodia) against pro-M oscow ones; authoritarian nationalists against Islamists (in the I ran-Iraq war); and a semi-absolute monarchy against authoritarian nationalists (K uwait against I raq). The U S currently props up a monarchy (Saudi A rabia) threatened by domestic anti-W estern I slamists. In some cases where both sides were undemocratic, the A mericans supported the less malign party (South against $\mathrm{N}$ orth $\mathrm{K}$ orea, $\mathrm{K}$ uwait against I raq, Cambodia's L on N ol against the $\mathrm{K}$ hmer Rouge), though the moral superiority of the A merican clients only became clear with hindsight in the $\mathrm{N}$ orth $\mathrm{K}$ orean and Cambodian cases. In some other cases, including Saudi Arabia, the relative (un)democratic-ness of the U S-supported and U S-opposed forces is more difficult to assess. ${ }^{16}$

The US has also opposed undemocratic governments in alliance with undemocratic opposition movements. Examples include the financing and arming of I slamic resistance to the Soviet occupation of A fghanistan in the 1980s and of U nita's long insurgency in Angola. ${ }^{17}$ (In fairness, U nita's undemocratic credentials were not clearly exposed until later, and not long after that the U S withdrew support from it.) On at least some criteria, the U S in both cases supported the more illiberal parties to

15 Sources for this paragraph include M ark F alcoff, 'A rgentina under the J unta, 1976-1982', in Pipes and G arfinkle (eds.), Friendly Tyrants, pp. 153-76; G eorges F auriol, 'M align N eglect: U S Policy towards H aiti under the Duvaliers', in Pipes and Garfinkle (eds.), Friendly Tyrants, pp. 177-200; Theodore F riend, 'T imely D aring: The U nited States and Ferdinand M arcos', in Pipes and Garfinkle (eds.), Friendly Tyrants, pp. 201-19; A dam Garfinkle, 'The N adir of G reek D emocracy', in Pipes and Garfinkle (eds.), Friendly Tyrants (1991a), pp. 63-87; G arfinkle and Luxenberg, 'The First'; R ichard N. H aass, 'South A frica under A partheid', in Pipes and Garfinkle (eds.), Friendly Tyrants, pp. 403-20; Paul B. Henze, 'W hy Turkey is not a Friendly Tyrant', in Pipes and Garfinkle (eds.), Friendly Tyrants, pp. 91-108; M artin Lasater, 'Taiwan under the K uomintang: A merica and the China Puzzle', in Pipes and G arfinkle (eds.), Friendly Tyrants, pp. 353-77; Edward Olsen, 'South K orea under M ilitary Rule: Friendly Tyrant?', in Pipes and Garfinkle (eds.), Friendly Tyrants, pp. 331-51; R iordan R oett, 'Paraguay without Stroessner', in Pipes and G arfinkle (eds.), Friendly Tyrants, pp. 286-306; M ichael Schatzberg, 'Zaire under M obutu: Consistencies and Contradictions of U S Policy', in Pipes and Garfinkle (eds.), Friendly Tyrants, pp. 421-47; J ames Theberge, 'The Collapse of the Somoza R egime', in Pipes and Garfinkle (eds.), Friendly Tyrants, pp. 109-29; L aF eber, 'The Tension', pp. 155-6, 162; R obinson, 'Promoting'; Blum, Rogue State; Campbell, 'K issinger'.

16 Sources for this paragraph include William Shawcross, Sideshow: Kissinger, Nixon, and the Destruction of Cambodia (L ondon: F ontana, 1980); OIsen, 'South K orea'; D ouglas Pike, 'South Vietnam: A utopsy of a Compound Crisis', in Pipes and Garfinkle (eds.), Friendly Tyrants, pp. 41-61; J onathan M arshall, 'Iraq: It's N ot A Iways So Simple', San Francisco Chronicle, 20 October, 2002; R oger M orris, 'A Tyrant 40 Y ears in the M aking', NYTimes.com, 16 M arch 2003; 〈http://www.neiconi.com/romania/index8.cfm〉.

17 Craig Baxter, 'The U nited States and Pakistan: the Zia Era and the A fghan Connection', in Pipes and Garfinkle (eds.), Friendly Tyrants, pp. 479-506; M arshall, 'Iraq'. 
conflict. Whatever the balance between them, it must the case that, ceteris paribus, the killing and injuring of civilians on behalf of undemocratic forces is more difficult to justify in liberal terms than in defence of democratic ones.

The record of direct (domestic and external) rule by the US is itself far from consistently democratic. The US was a leader in expanding the suffrage in the nineteenth century, but effectively enfranchised blacks in the South only in 1965, after most liberal democracies had achieved universal suffrage. A merican democratic practice, though notably strong in certain areas, is in others far from exemplary. The US displays many features of plutocratic government. Senatorial representation favours conservative rural states. As seen in 2000, the Electoral College system enables candidates to be elected to the presidency who have lost the popular vote. ${ }^{18}$

Externally, the US has ruled as a colonial power in a number of countries, including the Philippines (1898-1946) and N icaragua (almost continuously between 1912 and 1933). The U S has exercised an informal hegemony over L atin A merica since the enunciation of the M onroe D octrine in 1823, and wields disproportionate power in international institutions like the $U$ nited $\mathrm{N}$ ations Security Council and International M onetary $\mathrm{F}$ und, which significantly influence global governance.

The US has also been less than consistent in promoting a liberal-approved list of human rights globally, especially if we assume that these encompass modern rules of war. A merica's westward expansion involved the (often violent) ${ }^{19}$ displacement of indigenous Indian peoples. Southern states practised slavery until the 1865, racial segregation until the 1960s. The country today has the world's largest absolute and per capita prison population 20 (accompanied often by harsh prison conditions), and is unusual amongst liberal democracies in imposing the death penalty. Internationally US ground forces perpetrated atrocities in suppressing the Filipino independence struggle (1898-1902) and during the Korean and Vietnam Wars. A merican air forces inflicted massive civilian casualties in W orld W ar II, K orea and Indo-China. ${ }^{21}$ Washington has also backed governments that have massacred civilians, the most egregious post-1945 examples being Guatemala (1954-1980s),

18 R obert D ahl, How Democratic is the American Constitution? (N ew H aven, CT: Y ale U niversity Press, 2001). F or a recent critique of A merican plutocracy, see K evin Phillips, Wealth and Democracy: A Political History of the American Rich (N ew Y ork: Broadway Books, 2002).

19 R obert G ellately and Ben K iernan, 'The Study of M ass M urder and G enocide', in R obert G ellately and Ben K iernan (eds.), The Spectre of Genocide: Mass Murder in Historical Perspective (Cambridge, UK : Cambridge U niversity Press, 2003), pp. 3-6, at 22-4.

20 'A Stigma that N ever Fades', The Economist, 8 A ugust 2002: 〈http://www.economist.com/world/na/ displayStory.cfm?story_id $=1270755\rangle\rangle$; G ary Y ounge, '30\% of Black M en Will Go to Jail', The Guardian, 18 A ugust 2003.

21 Probably more than 200,000 civilians died in the Philippines war from various causes (Twentieth Century Atlas, 〈http://users.erols.com/mwhite28/warstat3.htm\#l nsurgency $\rangle$ ). E stimates of the numbers killed by A nglo-A merican bombing in World War II range between 760,000 and 1.1 million. See the Twentieth Century Atlas (〈http://users.erols.com/mwhite28/warstat1.htm\#R ussian〉). South V ietnamese and US forces may have been responsible for 475,000 V ietnamese civilian deaths (G ellately and K iernan, 'The Study', p. 18). These presumably include 20,000-65,000 N orth Vietnam civilians killed by U S bombing. On the latter, see Spencer Tucker, 'Casualties', in Spencer Tucker (ed.), Encyclopedia of the Vietnam War: A Political, Social, and Military History, vol. 1 (Santa Barbara, CA: A BC-CLIO, 1998), pp. 106-7, at 106; Twentieth Century Atlas at 〈http://users.erols.com/mwhite28/warstat2.htm\#V ietnam〉. Civilian casualty estimates for K orea, Cambodia and Laos are more difficult to come by. On the Cambodian bombing, see Shawcross, Sideshow. 
Pakistan (1971) and Indonesia (1965-6, 1975-9).22 The US quietly protected apartheid South A frica during the Cold W ar and today effectively supports I srael's collective punishment of W est Bank and Gaza Palestinians.

Since September 11th the U S has proclaimed a new guiding principle: opposition to 'terrorism' in all forms and its state sponsors. If by terrorism is meant armed opposition to governments, the US has repeatedly breached this principle, backing insurgencies in N azi-occupied Europe and, in the 1980s, in A fghanistan, A ngola, Cambodia, Ethiopia and $\mathrm{Nicaragua.} \mathrm{It} \mathrm{closely} \mathrm{supported} \mathrm{a} \mathrm{government} \mathrm{(Israel)}$ backing an armed militia in Lebanon, and protected another (South A frica) that sponsored guerrilla wars in Mozambique and Angola. If terrorism refers to the deliberate killing and injuring of civilians and captives by non-state groups, then some of these groups practised that (notably R enamo in M ozambique, A fghanistan's $\mathrm{M}$ ujahedin and the $\mathrm{K}$ hmer Rouge element of the anti-Vietnamese coalition in Cambodia). A nd if it refers to such action carried out by any group, including states, then U S backing for regimes that massacred civilians (like G uatemala, Indonesia and Pakistan) can be interpreted as support for state terrorism.

W e can (to summarise) safely say that the historical track record of the U S exhibits at least two of the hypocrisy subtypes suggested by Crisp and Cowton. The US possesses some of the faults it criticises in others; and it fails to live up to its proclaimed principles. US behaviour probably involves the other two kinds of hypocrisy as well: pretending moral goodness and approaching the matter of its own moral virtue unreflectively and complacently. We have not, however, offered empirical evidence for these further charges and indeed, as indicated earlier, have sought to avoid speculative and/or disputable claims about the sincerity or selfknowledge of U S foreign policy actors. The demonstrable forms of U S hypocrisy are sufficient to make the case.

What counterarguments against hypocrisy might defenders of US foreign policy offer? One might be that the U S's anti-democratic or rights-violating actions, though individually inconsistent with A merican principles, were part of a larger strategic effort whose aim was consistent with them. Thus US support for anti-communist dictators was (it might be argued) necessary to the successful prosecution of the struggle against a global totalitarian force which, if it had triumphed, would have extinguished the prospects for democracy everywhere.

Whatever its merits as a defence of A merican methods, such a justification of US foreign policy does not evade the charge of hypocrisy. It assumes what is disputable,

22 A ccording to G randin, over 200,000 were killed in G uatemala. See G reg Grandin, 'H istory, M otive, $\mathrm{L}$ aw and Intent: Combining $\mathrm{H}$ istorical and L egal M ethods in U nderstanding $\mathrm{G}$ uatemala's

1981-1983 G enocide', in G ellately and K iernan (eds.), The Spectre of Genocide, pp. 339-52, at 339.

The Twentieth Century Atlas cites figures of 1-3 million for Bengalis massacred by the Pakistan government 〈http://users.erols.com/mwhite28/warstat2.htm\#Bangladesh〉; see also R udolph J.

R ummel, Death by Government (N ew Brunswick, N J: Transaction Books, 1997); H itchens, 'T he Case'. A million or more may have been killed by the Indonesian regime. See Leslie D wyer and D egung Santikarma, " "When the W orld Turned to Chaos": 1965 and its A ftermath in Bali, Indonesia', in G ellately and K iernan (eds.), The Spectre of Genocide, pp. 289-305, at 289; J ohn G. Taylor, " "Encirclement and A nnihilation": The Indonesian Occupation of East Timor', in G ellately and K iernan (eds.), The Spectre of Genocide, p. 163-85, at 18. See also G uy Pauker, 'Indonesia under Suharto: the Benefits of A loofness', in Pipes and Garfinkle (eds.), Friendly Tyrants, pp. 379-99). A pre-1945 (or rather pre-1949) list would have to include U S support for the Guomindang, who killed up to 10 million during China's civil wars (R ummel, Death by Government; see also the Twentieth Century Atlas at 〈http://users.erols.com/mwhite28/warstat2.htm\#N ationalist〉). 
that all anti-democratic US behaviour during the Cold War was about defending democracy and human rights in the long-term, and none was about defending capitalism, capitalists or A merican great power interests. But leaving aside this motivational question, it is clear that, to avoid the charge of hypocrisy, A merican foreign policymakers during the Cold War would have had to admit to acting often in ways that were anti-democratic and inhumane and stand their ground on the need to use unjust means to secure just ends. These were not the terms in which the US publicly explained its Cold W ar policies (perhaps because A merican and world public opinion would, rightly, have considered a defence couched in these terms dubious).

Partisans of US foreign policy might mount a quite different defence: that while the US often gave priority to capitalism over democracy, in doing so it was being consistent with the A merican celebration of capitalism as fundamental to freedom. On this account of the A merican creed, capitalism might be entitled to defence against democratic majoritarianism. A t worst, privileging capitalism over democracy involved a trade-off between A merican values rather than a wholesale negation of them.

Such arguments would carry force if American policymakers had actually advanced them. A merican politicians have made the case that promoting free trade helps bring about democracy, ${ }^{23}$ but this cannot justify crushing democracy to bring about free trade. A merican elites have typically taken the view that democracy and markets are twinned desiderata, and that while they might be promoted at different speeds, pursuing one (especially supporting markets) assists the other. M ainstream A merican politicians and commentators have not, to my knowledge, publicly argued that capitalism is morally more meritorious than democracy or that it should sideline democracy in zero-sum contests between the two.

A third defence against the hypocrisy accusation might focus on the recent shift in A merican policy towards more consistent democracy promotion. ${ }^{24}$ It does seem that since the mid-1980s the U S has been less eager to back openly authoritarian forces against democratic ones; in some instances it has intervened discreetly or overtly on behalf of democratic opponents against its authoritarian former friends (notably in Chile after 1985, the Philippines in 1986, Haiti in 1994). It has also put more resources into assisting pro-democratic forces abroad through US Agency for International Development and the National Endowment for Democracy (founded in 1983).

Leaving aside the question of A merica's motivation in changing tack, it is nevertheless important to point out that this shift has been partial. Since the end of the Cold War the U S has backed Y eltsin's regime in R ussia and mostly kept on the right side of China. It has allied with autocratic A rab states in two Gulf W ars, and formed new alliances with authoritarian central A sian governments in prosecuting the Afghan campaign. The more recent ' $W$ ar on Terror' has also seen the US establish an extra-legal detention centre at G uantanamo Bay. Bush's flip-flop on the recent abortive coup in Venezuela - first tacitly supporting the armed overthrow of an elected leftist president, then backing off in embarrassment - nicely illustrates the

\footnotetext{
23 I kenberry, 'A merica's Liberal G rand Strategy', pp. 113-17.

24 On A merica's turn to democracy-promotion, see n. 9 above and also Thomas Carothers, 'Taking Stock of Democracy A ssistance', in Cox, I kenberry and Inoguchi (eds.), American Democracy Promotion, pp. 181-99.
} 
fact but also limits of the new democracy-promotion. ${ }^{25} \mathrm{~F}$ urthermore, while the US supports some authoritarians now, it also backed some democrats in the past. The A merican record has been ongoingly mixed, even if the mixture has altered across time.

A final defence of the U S against the charge of hypocrisy might turn the table on A merica's critics. Indeed this defence has been tried often enough, and its essential charge is accurate: that many of A merica's accusers are hypocritical themselves, criticising A merican human rights violations while standing by (often much worse) regimes that violate human rights simply because, say, they are socialist or anti-A merican. Valid though this countercharge is, it does not enable A merica to evade the hypocrisy accusation. It only permits the U S to claim that it is not uniquely hypocritical; and it is not useable against non-hypocritical critics.

\section{D oes it matter?}

US interventions in the name of democracy or humanitarian principles frequently encounter the charge of 'hypocrisy'. How, opponents ask, can a state that upholds democracy and human rights so hypocritically be trusted to defend them? Indeed, is it morally entitled to act to defend them, given its record? If a particular US intervention advances democracy and human rights, should it be opposed because A merica has elsewhere acted against these causes? The question is, for the liberal democrat, more than hypothetical - for in several historical instances, the US has intervened to support democracy and human rights internationally. It played an important role in the defeat of $\mathrm{Nazi}$ Germany and in the democratic postwar reconstruction of Germany and J apan. It pressed for improved human rights in the Soviet bloc and rescued democratic Berlin. More recently, it helped to protect Bosnian M uslims from ethnic cleansing in the former $Y$ ugoslavia, and its intervention may have been necessary to saving Bosnian K osovars from a similar fate. ${ }^{26}$ In some cases American interventions, though on behalf of undemocratic forces, probably spared countries more cruelly undemocratic fates (for example, G reece and South K orea after World War II). A nd the U S restrained the excesses of some of its

25 Christopher M arquis, 'Bush Officials met with V enezuelans who ousted L eader', NYTimes.com, 16 A pril 2002. I am not yet decided whether the U S's role in deposing H aiti's elected president in 2004 constitutes a second recent instance of A merican complicity in the overthrow of democracy. A ccording to some, Bertrand A ristide had by the time of his overthrow squandered his democratic legitimacy by countenancing fraudulent congressional elections and violence by his supporters (see Peter Dailey, ' $\mathrm{H}$ aiti: The F all of the House of A ristide', The New York Review of Books, L:4 (2003), pp. 41-7 and 'H aiti's Betrayal', The New York Review of Books, L:5 (2003), pp. 43-6). Others question whether his record was bad enough to warrant his forceful ejection from elective office and highlight anti-democratic elements in the coalition that ousted him.

26 The latter proposition is debatable. NATO did not go out of its way to reach a compromise with Y ugoslavia before its 1999 U S-led attack on the country, and its intervention almost certainly sparked the wholesale ethnic cleansing that the alliance then sought (successfully) to reverse. It is nevertheless possible to argue that Y ugoslavia was planning anyway to displace A lbanian K osovars and that it was beginning, through its fierce counter-insurgency coming on top of a decade of repressive rule, to implement its intention prior to the NATO attacks. If that is the case, the NATO attack amounted to a pre-emptive intervention in a gathering emergency. (It is debatable too whether as much effort as might reasonably be expected has been put into reversing the subsequent 
authoritarian clients, helping eventually to steer many of them in a more democratic direction. In liberal and democratic terms the US can do good.

Where an A merican intervention seems likely to advance democracy and human rights in a particular time and place, the charge of 'hypocrisy' is, surely, insufficient to ground opposition to it. That intervention is morally defensible on consequentialist grounds, irrespective of the motivation or behaviour elsewhere of the $\mathrm{U} \mathrm{S}$. I t is better to do good insincerely (or while doing bad elsewhere) than to do bad, sincerely or otherwise.

The US is anything but an ideal force for international democratic and humanitarian intervention. U niversalistic liberals should prefer international bodies with significant powers, and acting in accordance with liberal and democratic principles, to carry out humanitarian actions. Such bodies do not exist, partly because of US opposition to setting them up (as with the International Criminal Court). Sometimes there is no choice but to turn to a power like the $U S$ to do a job of intervention (even if US justification of its action by reference to the absence of effective international bodies constitutes hypocrisy in itself). The US is the world's only superpower, with the economic and military means to get its way much of the time. If in a particular situation it seems determined and able to deliver democratic and humanitarian advances at a tolerable cost, A merica's hypocrisy cannot, in itself, be a reason for challenging its attempt to do so. People are not required (say) to starve, or to accept enslavement or ethnic cleansing, just so that the rather abstract and sometimes luxurious virtue of consistency can be given its full due. R ealisation of democracy and human rights matters more than the moral consistency and honesty (or otherwise) of those who enforce them. Hypocrisy grates, but it is not in itself an intolerable evil.

This point is worth expanding. Duc de la R ochefoucauld observed centuries ago that hypocrisy is vice's tribute to virtue. ${ }^{27}$ This sentiment has been echoed more recently by Piers Benn and $\mathrm{R}$ uth $\mathrm{G}$ rant. $\mathrm{N}$ ot only does hypocritical action entail a 'public acknowledgement of moral standards'; the pretence to virtue can act as a 'genuine constraint' on immoral political action. ${ }^{28}$ Benn suggests that hypocrisy can promote morally useful fictions, provided that it is not exposed.29 W ith J udith Shklar, $\mathrm{G}$ rant prefers hypocrisy to the excessive purity of the political ideologue or religious zealot. 30 In these terms, a US constrained by hypocritical simulation of virtue (or indeed self-deceived as to its own virtue) is likely to be less cruel and dangerous than an A merica openly pursuing its self-interest across the world. And those who take what the U S preaches literally are likely to imbibe positive values, the better by which to judge A merica's own actions as well as those of others. There is surely something in these points.

harassment and displacement of Serbian and other minorities.) I am agnostic on these questions. F or differing takes on the K osovo intervention by writers who are not principled anti-interventionists, see the review article by Timothy G arton A sh, 'K osovo: was It W orth It?', New York Review of Books, X L VII:14 (2000), pp. 50-60 and Eric H erring, 'F rom R ambouillet to the K osovo A ccords: N A TO's W ar against Serbia and I ts A ftermath', International Journal of Human Rights, 4:3 (2000), pp. 225-45.

27 Cited in Oxford Dictionary of Quotations (Oxford and N ew Y ork: Oxford U niversity Press, 1996), p. 410.

28 Ruth W. Grant, Hypocrisy and Integrity: Machiavelli, Rousseau, and the Ethics of Politics (Chicago, IL and London: The U niversity of Chicago Press, 1997), p. 180.

29 Piers Benn, 'W hat is W rong with H ypocrisy?', International Journal of Moral and Social Studies, 8 (1993), pp. 223-35, pp. 232-4.

30 J udith N. Shklar, Ordinary Vices (Cambridge, M A and L ondon: The Belknap Press of H arvard U niversity Press, 1984), pp. 45-86; Grant, Hypocrisy and Integrity, pp. 50-3. 
Some might argue that the short-term benefits of a particular U S intervention are outweighed by the long term consequences of legitimating the interventionist propensity of a power that is likely often to do bad deeds in future. It should be borne in mind, though, what sort of short- and long-term consequences are being compared here. The immediate benefit of an intervention might be to save a population from massacre. The long-term disbenefit is the bolstering of a power liable to commit or sponsor future crimes. But the US is, on our reading, also likely to prevent future crimes. What is being weighed, then, is the rescue of people from virtually certain mass death against a speculative future that combines good and bad deeds. (The future being the future, it might also include a better-behaving $U \mathrm{~S}$, or a more effective global humanitarian regime.) These are not easily-compared quantities: we cannot know for certain the longer-range consequences of present-day actions. There are nevertheless good reasons to give greater weight to near-certain massacres than speculative ones, to the needs of actual living (but endangered) people than of those of possible future people. The case for such weighting is reinforced if we admit a deontological side-constraint, as I would: that individuals cannot be treated as means to an end, meaning, in this case, that the immediately suffering cannot be treated as expendable in the struggle to bring about an ideal international humanitarian future. Our on-balance conclusion is further supported if we allow that human agency can break the causal link between present good interventions and future bad ones. That is: that we can exert some control over what actually does happen further down the road. (N evertheless this objection is weighty enough to have implications for how we regard the hypocritical power. On this, see below.)

A t the same time hypocrisy is not a desirable or harmless trait. Pinpointing what is wrong with it is no simple matter. A s with other vices, philosophers debate whether it is wrong (if indeed it is) in itself or because of its consequences. ${ }^{31}$ The matter is complicated by the fact that hypocrisy is a second order or meta vice: it does not refer to particular substantive wrong or harmful actions, but to a relationship (of inconsistency) between actions, words and motives. Criticism of hypocrisy is often a proxy method of pursuing disagreements on substantive issues. If we cannot disturb an opponent's conviction, we may nevertheless be able to attack their public and self image by exposing their failure to abide by their own commitments. In this way the charge of hypocrisy can be, as Shklar notes, a weapon of 'psychic warfare' against moral opponents. ${ }^{32}$ Conversely, we are unlikely to attack as hypocritical substantive actions of which we approve. Critics of A merican hypocrisy typically seek to expose what they perceive to be substantively bad acts. It is these acts that ultimately matter, not the hypocrisy of the actor. But if so much of the criticism of hypocrisy is secondary to substantive disagreements about actions, why does ordinary moral discourse posit it as a vice, even as one of the most serious ones (as when it allows the apology 'at least I'm not a hypocrite')?33

$31 \mathrm{U}$ tilitarian-teleological and $\mathrm{K}$ antian-deontological critiques of hypocrisy, along with A ristotelian ones, are usefully surveyed by Spiegel, Hypocrisy, pp. 105-25.

32 Shklar, Ordinary Vices, p. 60.

33 Spiegel shows how hypocrisy is condemned across all major meta-ethical traditions. W ith K ittay she also demonstrates the long history of condemnation of it, especially in the Christian tradition. See Spiegel, Hypocrisy, pp. 105-25 and Eva F eder K ittay, 'H ypocrisy', in Lawrence C. Becker and Charlotte B. Becker (eds.), Encyclopedia of Ethics, 2nd edn. (N ew Y ork and L ondon: R outledge, 2001), pp. 819-824, at 820. 
A nti-consequentialist critics of hypocrisy argue that the intentions of the hypocrite are central to understanding hypocrisy and why it is wrong. Consequentialists, in focusing exclusively on the results of actions, cannot (they hold) account for its location among the vices. $Y$ et most critiques of hypocrisy that emphasise the value of sincerity and authenticity - the reflection of inner states in outer behaviour - can be rendered more plausibly in consequentialist terms. The harm that insincerity does results from its exposure, and the risk of exposure can ground a rule-consequentialist case for adjudging sincerity a virtue, at least in those areas where its absence is damaging. ${ }^{34}$ Sincerity matters more in, say, friendship than in everyday manners. In the case of politics we value the sincerity of comrades more than that of opponents. The insincerity of the latter matters only insofar as it shows them up before their comrades, and before their consciences. Highlighting it is the stuff of the aforementioned psychic warfare.

Other consequentialist arguments against hypocrisy apply more urgently to foreign policy and state behaviour. One of them is that hypocrisy subverts morality as a system. ${ }^{35}$ W hile particular hypocritical actions may produce defensible results, hypocritical behaviour threatens the moral foundations on which people stand. $\mathrm{H}$ ypocrisy may be a tribute to public moral standards but, at least when it is exposed, it can threaten them. By revealing the lack of 'moral seriousness' of some members of a community - especially those who are moral exemplars - it encourages cynicism in others. ${ }^{36} \mathrm{~F}$ urther, the disclosure of hypocritical deception undermines trust in human relationships, damaging moral communities. It can also undeservedly tarnish the worthwhile values and goals that hypocrites espouse. (To suggest that hypocrisy should therefore not be exposed is hardly an adequate response: the fact is that hypocrisy often will be exposed.)

A nother problem with hypocrisy recognisable to a consequentialist has already been touched on. Even if a hypocritical action does good, those of hypocritical disposition cannot be relied upon to do good in future, and might indeed use the prestige gained by the backing and success of a current intervention to justify or mask future, more dubious interventions. It is therefore advisable to criticise the hypocritical disposition and to be wary of the hypocrite. ${ }^{37}$

There is one persuasive deontological case that can be made against hypocrisy. It is the argument that a good reputation gained by undiscovered hypocritical action is unjust, in that it is acquired by less effort than the good reputation of the non-hypocrite. Hypocrisy, in these terms, represents an unjust distribution of benefits and burdens among individuals and their associations (including states), with the hypocrite getting an unfairly large ratio of benefits to burdens compared to the sincere and consistent. Egalitarians of various stripes can thus plausibly attack hypocrisy as a source of unmerited privilege.

If these arguments hold up, then hypocrisy deserves criticism even when associated with actions that yield morally desirable outcomes. If the US lacks 'moral

${ }^{34} \mathrm{~F}$ or a specification of areas where 'sincerity really matters', see Eva F eder K ittay, 'On H ypocrisy', Metaphilosophy, 13:3/4 (1982), pp. 277-89, at 279-80, 285.

35 Christine M CK innon, 'H ypocrisy, W ith a N ote on Integrity', American Philosophical Quarterly, 28:4 (1991), pp. 321-30; Eldon Soifer and Béla Szabados, 'H ypocrisy and Consequentialism', Utilitas, 10:2 (1998), pp. 168-94, at 182-9.

36 Crisp and Cowton, 'H ypocrisy', pp. 346-7.

37 Soifer and Szabados, 'H ypocrisy', pp. 178-85. 
seriousness' in its international dealings, this weakens global respect for the democratic and humanitarian causes it champions. I ts too-easy manipulation of truth opens the way to a wider dishonesty about the causes, facts and consequences of conflicts. It also subverts the authority of words used to describe desirable goals such as democracy and human rights.

F urther, if the US has behaved hypocritically in the past, its present and future actions require close and sceptical scrutiny. Every effort must be made to ensure that it does not interpret backing of a current intervention as approval of its interventionism in general or as a green light for future bad interventions.

As to unmerited reputational privilege, the spread of anti-A merican sentiment suggests that some of this has now been forfeited, but it remains intact in many parts of the world especially those (such as Poland and the Czech R epublic) that have benefited from past pro-democratic, pro-human rights A merican policies.

US foreign policy hypocrisy manifests itself not in a consistent contrast between proclaimed principle and behaviour (sometimes the US does act to realise its stated principles) but in a mixture of actions, some consistent and others not, with A merica's public beliefs. Certain individual U S actions are hypocritical when viewed in their own right (as when Washington supports a dictator in the name of democracy) but all A merican actions are, in a sense, part of a pattern of hypocrisy: A merican support for democracy in country $A$ is made problematic by its undermining of democracy in country B. The US does good for some peoples but not others (sometimes at the expense of others). As Chomsky notes, A merican foreign policy divides the world's oppressed into 'worthy' and 'unworthy' victims in ways that appear unrelated to genuine moral considerations. ${ }^{38} \mathrm{M}$ oreover the U S masks bad acts behind self-righteous reference to good acts (as when the U S recalls its past worthy interventions to justify a currently dubious one). This aspect of hypocrisy involving selectively good actions - is relatively little discussed in the recent literature on hypocrisy, which prefers to examine discrete examples of hypocritical action rather than to evaluate moral agents across time and space.

Criticism of an hypocritical pattern of foreign policy behaviour has a specific value. M ost obviously, it reaffirms the universalist principle of equal rights for all human beings globally that is challenged when some peoples (such as the French under $\mathrm{G}$ erman occupation, Czechs under Communism) benefit from pro-democratic US support and others (such as the Palestinians or G uatemalans) do not.

Public exposure of foreign policy inconsistency serves, additionally, to ease the justified burden of resentment felt by victims of the past bad behaviour of a power now claiming the high moral ground. Where the hypocrisy of their tormentor is exposed, they are at least spared the spectacle of seeing it receive universal approbation. It would be wrong to underestimate the role of just this type of resentment in the fury felt, say, by Palestinians towards U S efforts to 'liberate' A rab countries.

Finally, criticism of hypocritical selectivity invokes the idea that moral actors, whether singular or collective, are continuous through time, and must account for the whole of their record; and it speaks to the importance of memory. While the

38 A ccording to Chomsky, 'worthy' victims are those persecuted by A merica's enemies while the 'unworthy' suffer at the hands of U S allies. See N oam Chomsky, The New Military Humanism: Lessons from Kosovo (M onroe, M E: Common Courage Press, 1999), pp. 6, 8, 13, 19. 
importance of both continuity of moral personality and memory can be overstated, some notion of them is necessary to the redress of historical wrongs and appropriate lesson-learning for the future. The US (to take the case at hand) was not born yesterday, and will be around tomorrow. It must answer for what it did before, and (in future) for what it does now. Critique of A merican foreign policy hypocrisy (even in the case of a good intervention) is essential to clarifying the historical responsibilities of the US and to influencing it to do good always rather than selectively.

On the one hand, then, criticising hypocrisy is compatible with supporting the desirable action(s) of the hypocrite, including the hypocritical state. On the other, criticism must be levelled at the hypocrite irrespective of (and simultaneously with) that support, for it is directed at a general pattern of behaviour that offers a negative model for others. The hypocrisy of the interventionist is not a sufficient reason to oppose an intervention, but neither is the justice of an intervention sufficient reason to fall silent on the subject of the interventionist's hypocrisy.

But the matter is not settled quite so neatly. While its hypocritical character is insufficient reason to oppose an intervention, hypocrisy can help engender circumstances that make an intervention non-efficacious and thus insupportable; or wider negative consequences that outweigh the immediate benefits of an intervention. This is most likely to be true of what I term germane hypocrisy - hypocrisy directly relevant to the circumstances of a particular intervention rather than (merely) to the intervening power's more general record; hypocrisy that bears directly on the perceptions and actions of those affected by the intervention. The presence even of germane hypocrisy does not constitute sufficient grounds for opposing interventions. To this extent it is no different to non-germane hypocrisy. N evertheless germane hypocrisy is the more likely to produce (or contribute to) negative consequences that confound and outweigh the benefits of an intervention. Where it does so hypocrisy constitutes a legitimate object of comment and criticism within a wider consequentialist critique of an intervention.

The sort of hypocrisy that indirectly weakens the case for particular interventions can, I would argue (though I cannot fully elaborate the point here), be seen at work in A merican conduct of the war against terrorism so far. A case can be made that U S inconsistency in backing the I sraeli government, pro-western A rab dictatorships and authoritarian Islamist movements, while going militarily after designated 'rogue' states like Iraq and A fghanistan, subverts the goal of ending terrorism. It does this by depriving Arab and Muslim governments of the moral authority they need effectively to suppress terrorists. These governments are unable to explain to their subjects why terrorists harbouring legitimate grievances (notably against I srael) should be suppressed while the West sponsors state and opposition terrorism of its own. F urther, since A merican hypocrisy stokes the anger of A rabs and M uslims, it increases the probability that further cohorts of terrorists will spring from their ranks. Insofar as it elicits this sort of 'blowback', ${ }^{39}$ A merican foreign policy hypocrisy works against the larger purpose of the 'war on terror'.

A case can be made, secondly, that it undermines prospects for democratic advance in the $M$ iddle East and beyond. This is partly because A rab resentment at W estern double standards encourages the 'A rab street' to support defiant strongmen and diverts popular anger and political energy from domestic reform to anti-Israel

39 J ohnson, Blowback. 
and anti-W estern animus. Where Arab regimes are widely opposed by their own subjects, it is often by anti-Western, anti-democratic I slamists. To prevent their coming to power (an eventuality incumbent elites fear for varied reasons), A rab regimes resist providing them with democratic openings. The whole region is thus frozen in its current state of militarism and authoritarianism, and U S hypocrisy is one (indirect) reason why. H ypocrisy in supporting countries like I srael and Saudi A rabia is, in this case, directly germane to any assessment of the conduct and justification of the U S intervention in A fghanistan, in other countries where terrorists are based, and in Iraq. It indirectly generates reasons (to be precise, contributes to circumstances that ground reasons) for opposing current and planned U S interventions in the A rab and M uslim world, even where these latter produce some positive consequences (such as the overthrow of the Taliban in A fghanistan and Saddam H ussein's regime in I raq). This is not least because those positive results, even better results, might be achievable with less bloodshed if U S hypocrisy were addressed first.

\section{Addressing hypocrisy}

What, though, to do about hypocrisy? There is a negative response, which can be adopted in the face of all kinds of hypocrisy or just in cases of germane hypocrisy and that is to refuse to accept that the hypocritical power can usefully intervene abroad to foster democracy and human rights. For reasons already indicated - the fact that the US is the power most capable of defeating militarily gross violators of human rights - such an approach can amount to helpless passivity in the face of tyranny or aggression.

There is a more positive response: it is to demand that the hypocritical power cease being hypocritical, and that the good it does in one instance it should do in another. It is to support a particular good intervention (provided standard criteria of just war are satisfied), but to demand that the intervening power behave better in other (present and future) instances. The U S-led intervention in Bosnia and K osovo was, with important qualifications, worthy of support, despite the hypocritical character of the US and other countries carrying it out. $Y$ et it made sense during those interventions, as now, to say to the U S: you opposed ethnic cleansing in the Balkans; why do you tolerate it in I srael-Palestine? W hy did the U S enable A Ibanian K osovars to return home, but does so little to help Palestinian refugees?

Even supposing a particular intervention is worthy of support, the intervening power's hypocritical record justifies a wariness about its actions. If the power has behaved badly in the past, it could turn bad again. If it is doing good for wrong or insincere reasons, its real (hidden) reasons could cause it to start acting badly. A power's historical hypocrisy is a reason for a contemporary vigilance in monitoring its conduct. The proper fate of the proven hypocrite is not to be fully trusted.

In certain cases where hypocrisy is germane and produces wider or longer-term effects that undermine the local good done by an intervention, it must be appropriate to oppose that intervention unless and until the intervening power addresses its hypocrisy simultaneously with intervening. In wars such as those in A fghanistan and Iraq, a positive response is to oppose US intervention, but with a conditional opposition that might be rescinded provided that (inter alia) the US does other 
important and necessary things. In the run-up to the Iraq war, these would have included exercising firm pressure on Israel to deal justly with the Palestinians, withdrawing troops from A rab countries where they are unpopular, constructing a more humane, leadership-targeted sanctions regime for I raq and demanding the dismantling of weapons of mass destruction throughout the region, including by I srael. The presence of hypocrisy (germane or otherwise) cannot, of course, be the only consideration determining the right response to the Afghanistan and Iraq interventions: but given its ramifications in these cases, it should count for a lot.

Whether the hypocrisy is germane or not, its critics should advance one further argument: that if the US genuinely believes in the global promotion of democracy and human rights, it should support the creation and effective resourcing of international institutions committed to such ends. U niversalist liberals believe in morally consistent governance, and that effective international regulation cannot be provided by a single state accountable in the first instance to its own electors and interest groups, however powerful that state, however well-intentioned. It can be provided only by institutions representing diverse states and peoples. A merican unilateralism constitutes, in the context of current efforts to forge treaties and institutions that impartially enforce liberal-recognised international humanitarian standards, one more instance of criticism-worthy inconsistency, one more respect in which it is legitimate to demand that the world's unelected hyperpower behave less hypocritically. 